\title{
Contribution of Organic Amendments to Growth of Faba Bean and Maize Planted in Soil Exposed to Heavy Metals Pollution
}

\author{
H.M. El-Zemrany*, M. M. El-Shinnawi* and Riham M.N. \\ Faiyad $^{* *}$ \\ *Dept. of Soil Sci., Fac. Agric., Minufia University and ${ }^{* *}$ Soils, \\ Water \& Environment Rec., Inst., ARC, Egypt.
}

\begin{abstract}
( RGANIC materials, namely compost, biogas manure and humic acid, were employed, individually, to improve growth of plants cultivated in a chemically polluted alluvial clay soil. A mixture of heavy metals, i.e. $\mathrm{Zn}+\mathrm{Cu}+\mathrm{Pb}$ intentionally introduced to the soil. Two rates of each of the organic and mineral substrates were examined, i.e. $0.5 \& 1.0 \% \mathrm{C}$ for the organics and the permissible safe level of each mineral \& duplicate that level, all besides the controls of such treatments. Faba bean (Vicia faba), as a winter legume, and maize (Zea mays), as a summer cereal, were used as test crops. Greenhouse pot experiments were carried out to achieve the purpose of the study. Traits of plant growth had been measured at two periods after planting, i.e. $45 \& 90$ days for faba bean and $30 \& 60$ days for maize.

The applied organic amendments proved to control the hazardous action of the heavy metals added to the soil. Elevating the dose of such treatments more efficiently handicapped the mobility of the heavy metals in soil medium to the favour of availability of nutrients and their plant absorption. This had been positively reflected on plant growth traits, namely plant height, dry mass and main macro-nutrient contents (N,P\& K). Order among the organic substances used, as to diminish the passive action of used the heavy metals, was: humic acid> biogas manure> compost, at the first growth period, but compost and humic acid exchanged position later on. Faba bean relatively showed a lower susceptibility to the undesirable effect of the heavy metals than maize.
\end{abstract}

Keywords: Compost, Biogas manure, Humic acid, Chemically contamination, Bioremediation, Faba bean, Maize.

Major among the problems facing the agricultural production is soil pollution with heavy metals. Remediation (phytoremediation and bioremediation) of heavy metals in contaminated soils is necessary in order to reduce the risk related to the presence of heavy metals in soil to an environmental unacceptable level. Soil pollution could be regarded as malfunctioning of soil as an environmental component following its contamination with certain compounds as a result of human activities. Application of organic materials (biogas manure, farmyard manure, compost, poultry manure and humate) can reduce heavy metal activities in polluted soils by precipitation, adsorption, complexation and chelation (Chen et al., 2007). 
Accumulation of heavy metals in agricultural soils is increasing concern, due to the food safety issues and potential health hazards, as well as its detrimental effects on soil ecosystems. These metals have peculiar characteristics including that: (1) they do not decay with time, (2) They can be necessary or beneficial to plants at certain levels but can be toxic when exceeding specific thresholds, (3) they are always present at a background level of non-anthropogenic origin, their input in soils being related to weathering of parent rocks and pedogenesis and (4) they often occur as cations which strongly interact with the soil matrix. Consequently, heavy metals in soils can become mobile as a result of changing environmental conditions. This situation is referred to as "Chemical timing bomb". Sources of these elements in soils mainly include natural occurrence derived from parent materials and human activities. Anthropogenic inputs are associated with industrialization and agricultural activated deposition, such as atmospheric deposition, waste disposal, waste incineration, urban effluent, traffic emissions, fertilizer application and long-term application of wastewater into agricultural land. Apart from the source of heavy metals, which is mainly the industrial drainage, the physicochemical properties of soil also affect the concentration and mobility of heavy metals in soils. Organic matter and $\mathrm{pH}$ are the most important parameters controlling the accumulation and the availability of heavy metals in soil environment. It is necessary then to evaluate the relationship among these parameters and heavy metal accumulation in soil (Papafilippaki et al., 2007 and Bülent, 2012).

The present study was performed to clarify the effect, on plant growth, of a blend of heavy metals, i.e. zinc + lead + copper added to an agricultural soil amended with organic materials, namely compost, biogas manure and humic acid and cultivated with faba bean ( as a legume) and maize (as a cereal) crops.

\section{Materials and Methods}

Lay out

The present investigation had been carried out in order to clear up the role of some organic materials in controlling accidental hazards of heavy metals pollution on plant growth. An alluvial soil was intentionally treated with a mixture of certain heavy metals that probably reach the soils in Egypt. Two different major crops were employed as test plants.

\section{Soil}

\section{Materials}

Samples of an alluvial soil were collected from the surface layer $(0-30 \mathrm{~cm})$ of the Experimental Farm of the Faculty of Agriculture, Minufia University (Shibin El-Kom, Egypt). Data of initial features of such soil are presented in Table (1: a, b\& c).

\section{Organic amendments}

Compost, biogas manure and humic acid, representing the organic amendments were individually applied to the soil under consideration. Data of Egypt. J. Soil Sci. 56, No. 4 (2016) 
chemical analyses of those materials are shown in Table (2: a\&b). Such materials and their analytical data were provided by the Dept. of Agric. Microbiol.,Agric.Res.Center (Giza, Egypt).

\section{Plants}

Two different major field crops were used as test plants, namely faba bean "Vicia faba", as a winter legume (deep tap-rooted crop) and maize "Zea mays", as a summer cereal (shallow fibrous rooted crop).

Heavy metals used (artificially polluting agents " $P$ ")

Acetate salts of each of zinc " $\mathrm{Zn",}$ copper "Cu" and lead "Pb" were added together in a mixture, to the experimental soil. Such heavy metals are among the most chemical agents polluting soils in Egypt (Abou-El Naga et al., 1999).

TABLE 1. Initial analytical data of the studied soil.

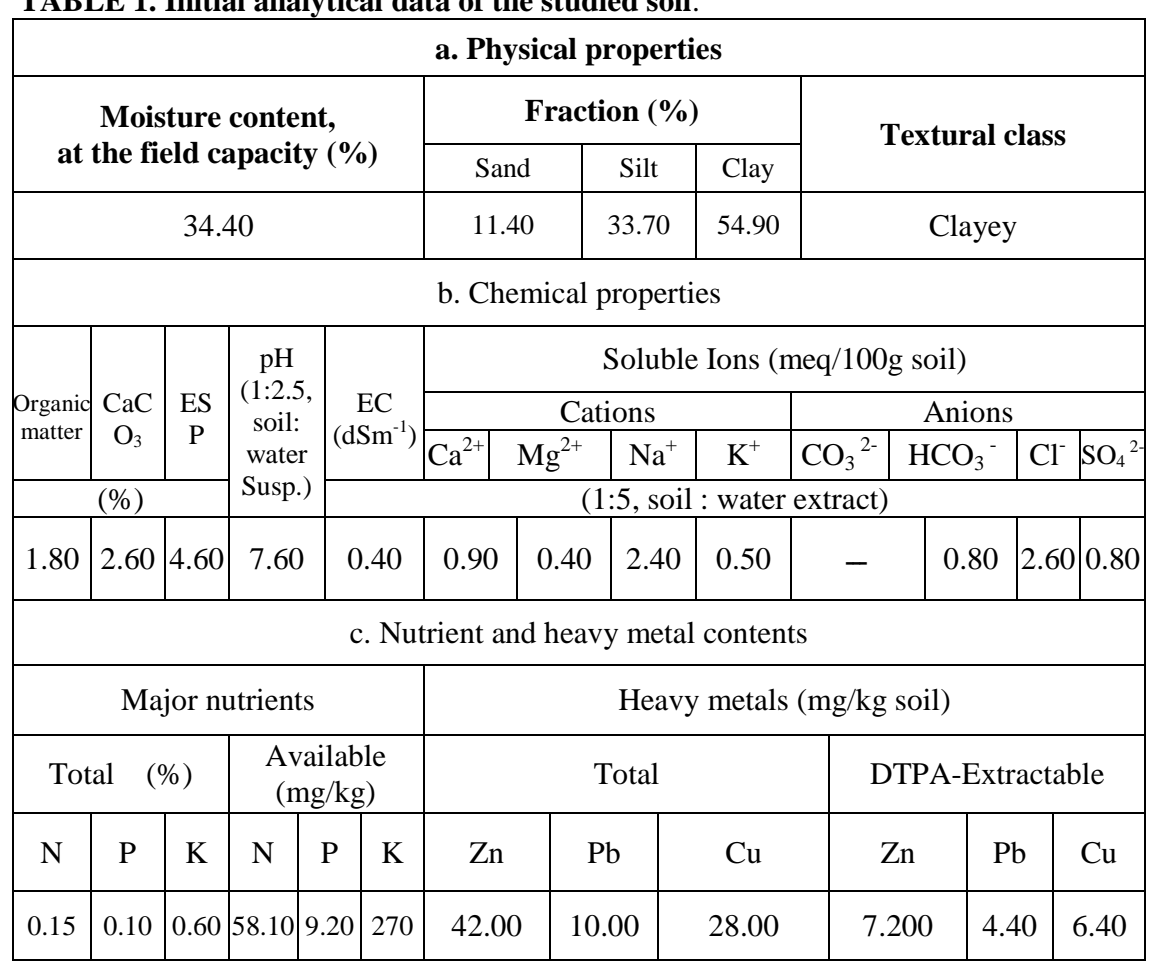

\section{Methods}

\section{Treatments}

- Controls (without organic materials $" \mathrm{O}_{0}$ " and without heavy metal pollutants " $\mathrm{P}_{0}$ ", as well as the dual control, e.g. without both organic materials and pollutants " $\left.\mathrm{O}_{0} \mathrm{P}_{0} "\right)$.

- One soil, three organic materials, two crops and one chemically polluting mixture consisted of three heavy metals.

Sub-treatments (actual experimental variables) 
Organic materials: Three organic amendments, i.e. compost, biogas manure and humic acid, were added, individually, at two rates $(0.5$ and $1.0 \%$ organic carbon basis).

Plants: Two crops, i.e. faba bean and maize were used as test plants.

Chemical pollutants: Three heavy metals, namely $\mathrm{Zn}, \mathrm{Cu} \& \mathrm{~Pb}$, at two levels of each element, were added as a mixture. According to Blaylock \& Huang (2000) and Adriano (2001), that the permissible safe levels of the heavy metals, particularly $\mathrm{Zn}, \mathrm{Cu}$ and $\mathrm{Pb}$, are 120,70 and $50 \mathrm{mg} \mathrm{kg}$ soil, respectively.

TABLE 2. Data of chemical analysis of the tested organic amendments.

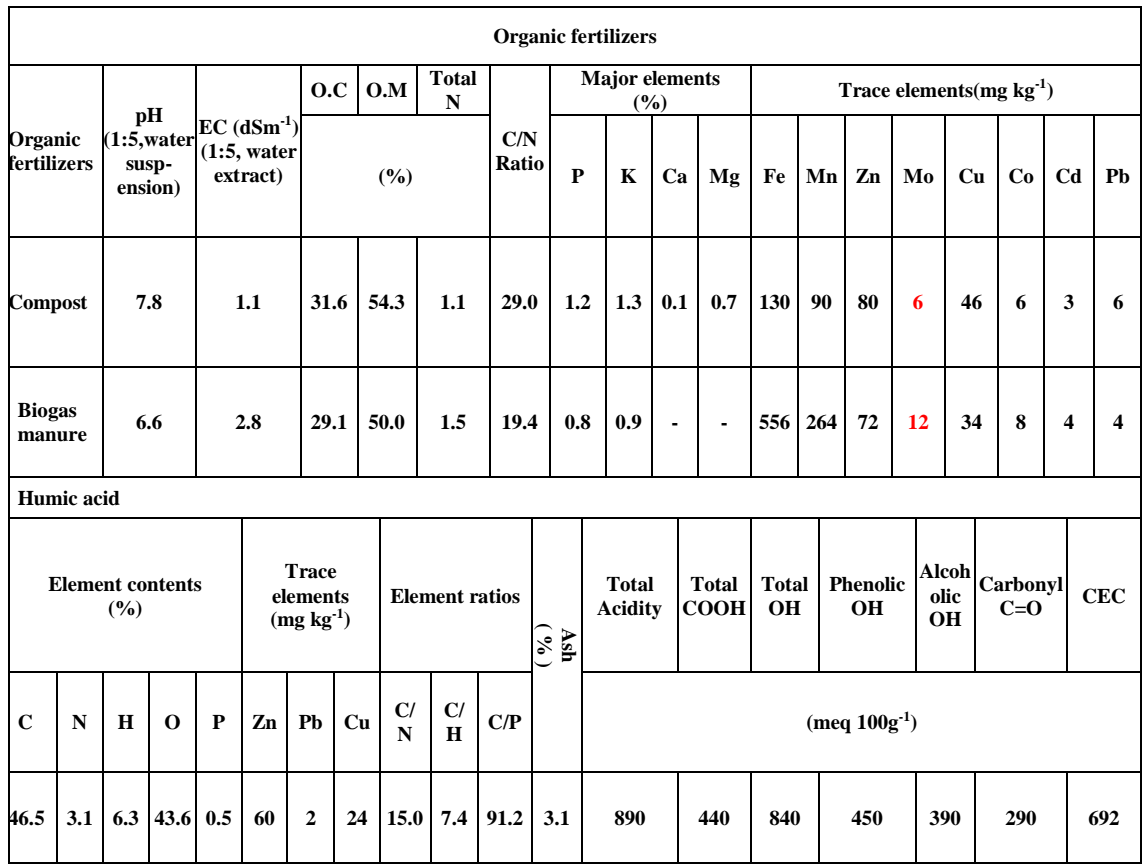

Consequently,the levels assigned for such sub-treatment, in the present study, were a collection of the allowed limits of such elements (Alloway, 1995), and another containing a duplicate level of each element in the mixture, i.e.:

$\mathrm{P}_{1}=120 \mathrm{Zn}, 70 \mathrm{~Pb}$ and $50 \mathrm{Cu} \mathrm{mg} \mathrm{kg}{ }^{-1}$ soil.

$\mathrm{P}_{2}=240 \mathrm{Zn}, 140 \mathrm{~Pb}$ and $100 \mathrm{Cu} \mathrm{mg} \mathrm{kg}{ }^{-1}$ soil.

\section{Experimental technique}

Greenhouse experiments had been conducted, using plastic pots (with $25 \mathrm{~cm}$ inter diameter $30 \mathrm{~cm}$ depth). Seven $\mathrm{kg}$ of the soil were packed in each pot after being thoroughly mixed with the calculated amount of each organic material,

Egypt. J. Soil Sci. 56, No. 4 (2016) 
i.e. rates of $0.5 \& 1.0 \% \mathrm{C}$. All pots were then moistened to $60 \%$ of the waterholding capacity of the soil for one week before sowing.

The experimental sub-treatments were arranged in a complete randomized block design with 6 replications of each. Seeds of faba bean were inoculated, before sowing, with the specific diazotrophs, namely Rhizobium leguminosarum. Eight seeds of faba bean or maize were sowed in each pot, according to the cultivation season of each crop (at $15^{\text {th }}$ October and $15^{\text {th }}$ April, respectively). After complete germination, seedlings were thinned to 4 plants /pot, and mixtures of heavy metal treatments $\left(\mathrm{P}_{1} \& \mathrm{P}_{2}\right)$ were then added with irrigation water. The experimental sub-treatments were fertilized with superphosphate for both crops (at a rate of $200 \mathrm{~kg} / \mathrm{fed}$.) before sowing, and both ammonium nitrate (at 50 and $200 \mathrm{~kg} / \mathrm{fed}$., for faba bean and maize, respectively) and potassium sulphate ( at a rate of $100 \mathrm{~kg} / \mathrm{fed}$. for each crop) after thinning, according to the recommendations of the Egyptian Ministry of Agriculture. Moisture content had been maintained, at the field capacity of the soil in all pots during the experimental period, via regular compensation every three days. Faba bean plants of three pots of each sub-treatment were carefully uprooted at each of two growth periods after planting. For faba bean, the first sampling took place after 45 days, through full tillering, and the second was performed onthe $90^{\text {th }}$ day. For maize, the first sampling occurred after 30 days and the later was performed on the $60^{\text {th }}$ day. Height of the plants was measured for the vegetative organs above the ground (shoots) just before dislocating the plants.

The collected whole plants were separated to shoots and roots. The shoots were further divided into two portions, the first one was oven dried at $105 \mathrm{C}^{\circ}$ to estimate the shoots dry weight, which were latter statistically analyzed (LSD), according to Snedecor and Cochran (1980). Whereas, the other shoots portion was oven dried at $70 \mathrm{C}^{\circ}$ to be prepared for chemical analysis (determination of main macro-nutrient contents "NPK"). $0.2 \mathrm{~g}$ of the dried (at $70 \mathrm{C}^{\mathrm{O}}$ ) plant materials were digested using a mixture of $1: 3$ concentrated perchloric acid: sulphoric acid, for elemental determinations (Cottenie et al., 1982).

\section{Laboratory determinations}

Initial soil analysis

Physical properties.(Klute, 1986):

- Mechanical analysis was determined by the universal pipette method, using sodium oxalate as a dispersing agent.

Chemical properties. (Page et al., 1982)

- Organic matter content was assessed by means of Walkly and Black method.

- Soil pH value was measured, in the 1:2.5 soil-water suspension, using standard glass electrodes ( $\mathrm{pH}$ meter).

- Calcium carbonate content was determined volumetrically, using a calcimeter.

- Total salinity (EC) was determined in the 1:5 soil/water extract, using an electrical conductivity meter (salt bridge).

Egypt. J. Soil Sci. 56, No. 4 (2016) 
- Soluble ions, i.e. the cations $\mathrm{Ca}^{2+}, \mathrm{Mg}^{2+}, \mathrm{K}^{+} \& \mathrm{Na}^{+}$and the anions $\mathrm{CO}_{3}{ }^{2-}, \mathrm{HCO}_{3}{ }^{-}$, $\mathrm{Cl}^{-} \& \mathrm{SO}_{4}{ }^{2-}$ were determined in the 1:5 soil- water extract, following the traditional standard methods.

- $\mathrm{Zn}, \mathrm{Cu}$ and $\mathrm{Pb}$ were determined by atomic absorption spectrophotometer.

- Nitrogen was determined, following the conventional method by means of a semi-micro-steam Kjeldahl distillation apparatus.

-Phosphorus was determined colourimetrically, by photoelectric colourimeter, applying the stannous chloride- sulphoric acid method.

- Potassium was determined by flame photometer.

Plant analysis: Contents of N, P \&K in the acid digest of plant shoots were determined, at the two growth periods, as noted above for the soil.

Calculations: Raw results ( analytical data of the replicates means of the various sub-treatments) were further calculated on the dry weight basis of the plants and/or the soil, as convenient.

Rates of the relative changes of the final results ( as percent ) "RC\%" were calculated for the result tabulated for a particular sub-treatment, referring to the result of the specific dual control (without both organic amendments and pollutants $\left." \mathrm{O}_{0} \mathrm{P}_{0} "\right)$.

\section{Results and Discussion}

\section{Height of faba bean and maize plants}

Data presented in Tables $3 \& 4$ showed that, application of the organic materials (compost, biogas manure or humic acid), in absence of added heavy metals, resulted in great upshifts in the height of faba bean and maize plants, at both the first and second growth periods, compared with the control $\left(\mathrm{O}_{0}\right)$. Higher values were recorded at the application rate of $1.0 \%$ O.C, above those at $0.5 \%$ O.C in all experimental treatments. Humic acid had a superior influence on such measure, particularly at the first growth period. Enhancement of the different organic amendments on the height of both plants could be arranged as follows: humic acid < biogas manure < compost<un-amended soil. However, at the second plant sampling, position of the humic acid was replaced with the compost.

Concerning the effect of chemical pollutants mixture, namely $\mathrm{Zn}+\mathrm{Cu}+\mathrm{Pb}$ added to the organic un-amended soil " $\mathrm{O}_{0}$ ", on plants height at both sampling times, data revealed that, the introduced heavy metals at their lower level $\left(\mathrm{P}_{1}\right)$ exerted inconsisted changes tending to show very slight increasesor even no effect, whilst the higher level $\left(\mathrm{P}_{2}\right)$ was inhibitory. Related results were reported by Chen et al. (2007). 
On the other hand, application of the organic amendments, at their both rates, to the polluted soil improved the harmful effect of heavy metals mixture added in all cases. Increasing the dose of organic amendments application to the polluted soil, more positive effect occurred on reducing the hazardous action on plant height. Generally, faba bean plants positively responded better than those of maize. Humic acid had superior influences on such measure at the first growth period, but at the second period, compost appeared to be the prime. Related results were obtained by Stathi et al. (2007); Angelova et al. (2010) and Sweed (2013).

TABLE 3. Influence of organic amendments on the shoot height of Faba Bean plants grown on the chemically polluted soil.

\begin{tabular}{|c|c|c|c|c|c|c|c|c|c|}
\hline \multirow{3}{*}{\multicolumn{2}{|c|}{$\begin{array}{l}\text { Organic } \\
\text { Amendments and } \\
\text { their Application } \\
\text { Rate (\%OC) }\end{array}$}} & \multicolumn{4}{|c|}{ First Growth Period (45 days) } & \multicolumn{4}{|c|}{ Second Growth Period (90 days) } \\
\hline & & \multicolumn{8}{|c|}{ Levels of Pollutants Mixture $(\mathrm{Zn}+\mathrm{Cu}+\mathrm{Pb})^{*}$} \\
\hline & & $\mathbf{P}_{\mathbf{0}}$ & $\mathbf{P}_{1}$ & $\mathbf{P}_{2}$ & Mean & $\mathbf{P}_{\mathbf{0}}$ & $\mathbf{P}_{1}$ & $\mathbf{P}_{2}$ & Mean \\
\hline & & \multicolumn{8}{|c|}{ Height of Plant Shoots ( cm ) } \\
\hline Control & $\mathrm{O}_{0}$ & 48.5 & 49.0 & 40.3 & 45.8 & 83.9 & 83.0 & 78.5 & 81.8 \\
\hline \multirow{3}{*}{ Compost } & 0.5 & 66.0 & 68.3 & 66.5 & 66.9 & 108.9 & 110.5 & 108.0 & 105.8 \\
\hline & 1.0 & 70.0 & 72.2 & 71.4 & 71.2 & 109.3 & 112.5 & 108.0 & 109.9 \\
\hline & Mean & 61.5 & 63.2 & 59.4 & - & 100.7 & 102.0 & 98.2 & - \\
\hline \multirow{3}{*}{$\begin{array}{l}\text { Biogas } \\
\text { manure }\end{array}$} & 0.5 & 72.4 & 74.0 & 73.2 & 73.2 & 106.5 & 105.5 & 103.0 & 105.0 \\
\hline & 1.0 & 76.4 & 74.5 & 73.4 & 74.8 & 107.0 & 106.0 & 104.5 & 105.8 \\
\hline & Mean & 65.8 & 65.8 & 62.3 & - & 99.1 & 98.2 & 95.3 & - \\
\hline \multirow{3}{*}{$\begin{array}{l}\text { Humic } \\
\text { acid }\end{array}$} & 0.5 & 80.6 & 84.0 & 82.4 & 82.3 & 90.1 & 89.5 & 88.0 & 89.2 \\
\hline & 1.0 & 83.7 & 85.1 & 83.5 & 84.1 & 94.2 & 92.9 & 90.4 & 92.5 \\
\hline & Mean & 70.9 & 72.7 & 68.7 & - & 98.4 & 88.5 & 85.6 & - \\
\hline
\end{tabular}


TABLE 4. Influence of organic amendments on the shoot height of Maize plants grown on the chemically polluted soil.

\begin{tabular}{|c|c|c|c|c|c|c|c|c|c|}
\hline \multirow{4}{*}{\multicolumn{2}{|c|}{$\begin{array}{l}\text { Organic } \\
\text { Amendments and } \\
\text { their Application } \\
\text { Rate (\%OC) }\end{array}$}} & \multicolumn{4}{|c|}{ First Growth Period (30 days) } & \multicolumn{4}{|c|}{ Second Growth Period (60 days) } \\
\hline & & \multicolumn{8}{|c|}{ Levels of Pollutants Mixture $(\mathrm{Zn}+\mathrm{Cu}+\mathrm{Pb}) *$} \\
\hline & & $\mathrm{P}_{0}$ & $\mathrm{P}_{1}$ & $\mathrm{P}_{2}$ & Mean & $\mathrm{P}_{0}$ & $\mathrm{P}_{1}$ & $\mathrm{P}_{2}$ & Mean \\
\hline & & \multicolumn{8}{|c|}{ Height of Plant Shoots ( $\mathrm{cm}$ ) } \\
\hline Control & $\mathrm{O}_{0}$ & 55.0 & 56.0 & 52.2 & 54.4 & 96.0 & 89.0 & 74.5 & 86.5 \\
\hline \multirow{3}{*}{ Compost } & 0.5 & 61.5 & 64.5 & 60.0 & 62.0 & 110.5 & 98.5 & 84.0 & 97.7 \\
\hline & 1.0 & 65.4 & 66.9 & 64.0 & 65.4 & 114.4 & 104.0 & 100.5 & 106.3 \\
\hline & Mean & 60.6 & 62.5 & 58.7 & - & 107.0 & 97.2 & 86.3 & - \\
\hline \multirow{3}{*}{$\begin{array}{l}\text { Biogas } \\
\text { manure }\end{array}$} & 0.5 & 64.2 & 68.0 & 62.0 & 64.1 & 102.5 & 90.5 & 88.5 & 93.8 \\
\hline & 1.0 & 68.4 & 70.0 & 65.0 & 67.8 & 105.5 & 94.5 & 90.5 & 96.8 \\
\hline & Mean & 62.5 & 64.7 & 59.7 & - & 101.3 & 91.3 & 84.5 & - \\
\hline \multirow{3}{*}{$\begin{array}{l}\text { Humic } \\
\text { acid }\end{array}$} & 0.5 & 70.5 & 72.5 & 71.0 & 71.3 & 98.5 & 87.5 & 85.5 & 90.5 \\
\hline & 1.0 & 82.0 & 73.5 & 72.0 & 75.8 & 99.0 & 89.2 & 87.0 & 91.7 \\
\hline & Mean & 69.2 & 67.3 & 65.1 & - & 97.8 & 88.6 & 82.3 & - \\
\hline
\end{tabular}

$* \mathrm{P}_{0}=$ Control ( no addition of heavy metals)

$\mathrm{P}_{1}=120 \mathrm{Zn}+50 \mathrm{Cu}+70 \mathrm{~Pb} \mathrm{mg} \mathrm{kg}{ }^{-1}$ soil.

$\mathrm{P}_{2}=240 \mathrm{Zn}+100 \mathrm{Cu}+140 \mathrm{~Pb} \mathrm{mg} \mathrm{kg}^{-1}$ soil.

\section{Dry matter mass of faba bean and maize plants}

Data appearing in Tables $5 \& 6$ demonstrated that, application of the organic amendments (compost, biogas manure or humic acid), to the natural soil ( unpolluted " $\mathrm{P}_{0}$ "), significantly augmented the dry matter mass of both faba bean and maize plants, at the two growth periods. Higher rates of such materials, as well as advancing the sampling time exhibited better results. Rates of the relative change of the treatments confirmed such outcomes, i.e. the RC\% for faba bean ranged from 7.6 to $59.1 \%$ at the first sampling and from 29.3 to $54.9 \%$ at the second sampling. The corresponding values for maize were 5.5 to 47.3 and 14.9 to $44.6 \%$, respectively. Type and rate of organic additives and time of plant sampling governed the obtained RC values. At the first growth period, effect of the different types of organic amendments on dry matter mass of the test plants, could be again ranked as follows: humic acid < biogas manure $<$ compost < un-amended soil, while at the second growth period, the order was: compost $<$ biogas manure $>$ humic acid $>$ un-amended soil. Similar results were obtained by Eisa et al. (2010); Saad (2013) and Sweed (2013). 
TABLE 5. Influence of organic amendments on dry matter mass of the shoots of Faba Bean plants grown on the chemically polluted soil.

\begin{tabular}{|c|c|c|c|c|c|c|c|c|c|c|c|c|c|c|c|}
\hline \multirow{5}{*}{\multicolumn{2}{|c|}{$\begin{array}{l}\text { Organic } \\
\text { Amendments } \\
\text { and their } \\
\text { Application } \\
\text { Rate (\%OC) }\end{array}$}} & \multicolumn{7}{|c|}{ First Growth Period (45 days) } & \multicolumn{7}{|c|}{ Second Growth Period (90 days) } \\
\hline & & \multicolumn{14}{|c|}{ Levels of Pollutants Mixture $(\mathrm{Zn}+\mathrm{Cu}+\mathrm{Pb}) *$} \\
\hline & & \multicolumn{2}{|c|}{$\mathbf{P}_{0}$} & \multicolumn{2}{|c|}{$\mathbf{P}_{1}$} & \multicolumn{2}{|c|}{$P_{2}$} & \begin{tabular}{|c|} 
Mea \\
n
\end{tabular} & \multicolumn{2}{|c|}{$\mathbf{P}_{0}$} & \multicolumn{2}{|c|}{$\mathbf{P}_{1}$} & \multicolumn{2}{|c|}{$\mathbf{P}_{2}$} & \multirow[t]{2}{*}{ Mean } \\
\hline & & \multicolumn{13}{|c|}{ Dry Weight of Plant Shoots and its Relative Changes (RC\%) } & \\
\hline & & $\mathrm{g} / \mathrm{pot}^{* *}$ & $\mathrm{RC} \%$ & $\mathrm{~g} / \mathrm{pot}$ & $\mathrm{RC} \%$ & $\mathrm{~g} / \mathrm{pot}$ & $\mathrm{RC} \%$ & $\mathrm{~g} / \mathrm{pot}$ & $\mathrm{g} / \mathrm{pot}$ & RC\% & $\mathrm{g} / \mathrm{pot}$ & $\mathrm{RC} \%$ & $\mathrm{~g} / \mathrm{pot}$ & $\mathrm{RC} \%$ & g/pot \\
\hline Control & $\mathrm{O}_{0}$ & 13.2 & 0.0 & 12.2 & -7.6 & 9.3 & -29.5 & 11.6 & 16.4 & 0.0 & 13.8 & -15.9 & 10.4 & -36.6 & 13.5 \\
\hline \multirow{3}{*}{ Compos } & 0.5 & 14.2 & 7.6 & 13.2 & 0.0 & 12.4 & -6.1 & \begin{tabular}{|l|}
13.3 \\
\end{tabular} & 24.5 & 49.4 & 21.8 & 32.9 & 19.4 & 18.3 & 21.9 \\
\hline & 1.0 & 15.3 & 15.9 & 13.3 & 0.7 & \begin{tabular}{|l|}
12.9 \\
\end{tabular} & -2.3 & 13.8 & \begin{tabular}{|l|}
25.4 \\
\end{tabular} & 54.9 & \begin{tabular}{|l|}
23.1 \\
\end{tabular} & 40.9 & 21.8 & 32.9 & 23.4 \\
\hline & \begin{tabular}{|l} 
Mean \\
\end{tabular} & 14.2 & - & 12.9 & - & 11. & - & - & 22.1 & - & 19.6 & - & \begin{tabular}{|l|}
17.2 \\
\end{tabular} & - & - \\
\hline \multirow{3}{*}{$\begin{array}{l}\text { Biogas } \\
\text { manure }\end{array}$} & 0.5 & 17.6 & 33.3 & 14.8 & 12.1 & 13.8 & 4.5 & 15.4 & 23.2 & 41.5 & 18.9 & 15.2 & \begin{tabular}{|l|}
16.9 \\
\end{tabular} & 3.1 & 19.7 \\
\hline & 1.0 & 18.5 & 40.2 & 15.9 & \begin{tabular}{|l|}
20.5 \\
\end{tabular} & \begin{tabular}{|l|}
14.8 \\
\end{tabular} & \begin{tabular}{|l|}
12.1 \\
\end{tabular} & 16.4 & \begin{tabular}{|l|}
23.8 \\
\end{tabular} & 45.1 & 20.4 & 24.4 & \begin{tabular}{|l|}
17.9 \\
\end{tabular} & 9.1 & 20.7 \\
\hline & Mean & 16.4 & - & 14.3 & - & 12.6 & - & - & 21.1 & - & 17.7 & - & 15.1 & - & - \\
\hline \multirow{3}{*}{$\begin{array}{l}\text { Humic } \\
\text { acid }\end{array}$} & 0.5 & 20.1 & 52.3 & 16.4 & 24.2 & 15.3 & 15.9 & 17.3 & 21.2 & 29.3 & 17.2 & 4.9 & 16.8 & 2.4 & 18.4 \\
\hline & 1.0 & 21.0 & 59.1 & 17.5 & 32.6 & \begin{tabular}{|l|}
16.4 \\
\end{tabular} & 24.2 & 18.3 & 22.4 & 36.6 & 18.8 & 14.6 & 17.6 & 7.3 & 19.6 \\
\hline & Mean & 18.1 & - & 15.4 & - & 13.7 & - & - & 20.0 & - & 16.6 & - & 14.9 & - & - \\
\hline \multicolumn{2}{|c|}{ LSD, at 0.05} & \multicolumn{7}{|c|}{$\begin{array}{c}\text { Organic materials "O.M." = }=0.42 \\
\text { Pollution }=0.31 \\
\text { O.M. Pollution }=1.20\end{array}$} & \multicolumn{7}{|c|}{$\begin{array}{c}\text { Organic materials "O.M." }=0.42 \\
\text { Pollution }=0.31 \\
\text { O.M. Pollution }=1.32\end{array}$} \\
\hline
\end{tabular}

$\mathrm{P}_{0}=$ Control ( no addition of heavy metals).

$\mathrm{P}_{1}=120 \mathrm{Zn}+50 \mathrm{Cu}+70 \mathrm{~Pb} \mathrm{mg} \mathrm{kg}^{-1}$ soil.

$\mathrm{P}_{2}=240 \mathrm{Zn}+100 \mathrm{Cu}+140 \mathrm{~Pb} \mathrm{mg} \mathrm{kg}^{-1}$ soil.

**** Each pot contained 4 plants

TABLE 6. Influence of organic amendments on dry matter mass of the shoots of Maize plants grown on the chemically polluted soil.

\begin{tabular}{|c|c|c|c|c|c|c|c|c|c|c|c|c|c|c|c|}
\hline \multirow{5}{*}{\multicolumn{2}{|c|}{$\begin{array}{l}\text { Organic } \\
\text { Amendments } \\
\text { and their } \\
\text { Application } \\
\text { Rate (\%OC) }\end{array}$}} & \multicolumn{7}{|c|}{ First growth period (30 days) } & \multicolumn{7}{|c|}{ Second growth period (60 days) } \\
\hline & & \multicolumn{14}{|c|}{ Levels of Pollutants Mixture $(\mathrm{Zn}+\mathrm{Cu}+\mathrm{Pb})^{*}$} \\
\hline & & \multicolumn{2}{|r|}{0} & \multicolumn{2}{|c|}{$\mathbf{P}_{1}$} & \multicolumn{2}{|c|}{$\mathbf{P}_{2}$} & \begin{tabular}{|c} 
Mea \\
n
\end{tabular} & \multicolumn{2}{|c|}{$\mathbf{P}_{0}$} & \multicolumn{2}{|c|}{$\mathbf{P}_{1}$} & \multicolumn{2}{|c|}{$\mathbf{P}_{2}$} & Mea \\
\hline & & \multicolumn{14}{|c|}{ Dry Weight of Plant Shoots and its Relative Changes (RC\%) } \\
\hline & & $g /$ pot $^{* *}$ & RC\% & $\mathrm{g} / \mathrm{pot}$ & $\mathrm{C} \%$ & $\mathrm{~g} / \mathrm{pot}$ & RC $\%$ & g/pot & $\mathrm{g} / \mathrm{pot}$ & RC\% & $\mathrm{g} / \mathrm{pot}$ & $\mathrm{RC} \%$ & $\mathrm{~g} / \mathrm{pot}$ & RC\% & $\mathrm{g} / \mathrm{p}$ \\
\hline & $\mathrm{O}_{0}$ & 11.0 & 0.0 & 9.2 & -16.4 & 7.0 & -36.4 & 9.1 & 14.8 & 0.0 & 12.0 & -18.9 & 8.0 & -45.9 & 11.6 \\
\hline \multirow{3}{*}{ Compost } & 0.5 & 11.6 & 5.5 & 10.4 & -5.5 & 8.1 & -26.4 & 10.0 & 20.6 & 39.2 & 18.8 & 27.0 & 16.9 & 14.2 & 18.8 \\
\hline & 1.0 & 2.4 & 12.7 & 10.9 & -0.9 & 10.2 & -7.3 & 11.2 & 21.4 & 44.6 & 20.1 & 35.8 & 18.8 & 27.0 & 20.1 \\
\hline & $\mathrm{Mc}$ & 11.7 & - & 2 & 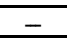 & & - & - & 18.9 & - & 0 & - & 14.6 & - & - \\
\hline \multirow{3}{*}{$\begin{array}{l}\text { Biogas } \\
\text { manure }\end{array}$} & 0.5 & 12.8 & 16.4 & 11.2 & 1.8 & 10.3 & -6.4 & 11.4 & 18.9 & 27.7 & 16.1 & 8.8 & 15.0 & 1.4 & 16.7 \\
\hline & 1.0 & 13.9 & 26.4 & 12.3 & \begin{tabular}{|l|}
11.8 \\
\end{tabular} & \begin{tabular}{|l|}
11.9 \\
\end{tabular} & 8.2 & 12.7 & 20.2 & 36.5 & 17.5 & 18.2 & 16.1 & 8.8 & 17.9 \\
\hline & $\mathrm{Mes}$ & 12.6 & - & 10.9 & - & 9.7 & - & - & 18.0 & - & 15.2 & - & 13.0 & - & - \\
\hline \multirow{3}{*}{$\begin{array}{l}\text { Humic } \\
\text { acid }\end{array}$} & 0. & 15.4 & 40.0 & 12.9 & 17.3 & 12.6 & 14.5 & 13.6 & 17.0 & 14.9 & 14.2 & -4.1 & 13.2 & -10.8 & 14.8 \\
\hline & 1.0 & 16.2 & 47.3 & 15.0 & 36.4 & 12.8 & 16.4 & 14.7 & 18.1 & 22.3 & 16.7 & 15.7 & 14.6 & -1.4 & 16.5 \\
\hline & $\mathrm{Mea}$ & 4.2 & - & 12.4 & - & \begin{tabular}{|l|}
10.8 \\
\end{tabular} & - & - & 16.6 & - & 14.3 & - & 11.9 & - & - \\
\hline \multicolumn{2}{|c|}{ LSD, at 0.05} & \multicolumn{7}{|c|}{$\begin{array}{c}\text { Organic materials "O.M." }=0.44 \\
\text { Pollution }=0.44 \\
\text { O.M. Pollution }=1.32\end{array}$} & \multicolumn{7}{|c|}{$\begin{array}{c}\text { Organic materials "O.M." }=0.52 \\
\text { Pollution }=0.52 \\
\text { O.M. Pollution }=1.42\end{array}$} \\
\hline
\end{tabular}

$\mathrm{P}_{0}=$ Control (no addition of heavy metals).

$\mathrm{P}_{1}=120 \mathrm{Zn}+50 \mathrm{Cu}+70 \mathrm{~Pb} \mathrm{mg} \mathrm{kg}^{-1}$ soil.

$\mathrm{P}_{2}=240 \mathrm{Zn}+100 \mathrm{Cu}+140 \mathrm{~Pb} \mathrm{mg} \mathrm{kg}^{-1}$ soil.

$$
{ }^{* *} \mathrm{RC} \% \quad \frac{\text { Result of a particular subtreatment }- \text { result of the dual control " } \mathrm{O}_{0} \mathrm{P}_{0} \text { " }}{\text { Result of the dual control " } \mathrm{O}_{0} \mathrm{P}_{0} \text { " }}
$$

*** Each pot contained 4 plants. 
In regard to the effect of heavy metals mixture $(\mathrm{Zn}+\mathrm{Cu}+\mathrm{Pb})$ added to the soil at its two levels $\left(\mathrm{P}_{1} \& \mathrm{P}_{2}\right)$, in absence of the organic treatments" $\mathrm{O}_{0}$ ", on the dry matter mass of faba bean and maize plants, at both growth periods, data revealed that those pollutants decreased the dry matter mass of the two plants, as compared with the control" $\mathrm{P}_{0}$ ". Such inhibition increased with elevating the heavy metals level $\left(\mathrm{P}_{2}\right)$, as well as by advancing the time of samples collection. The RC rates for faba bean were -7.6 to $-29.5 \%$ for $\mathrm{P}_{1} \& \mathrm{P}_{2}$ and-15.9 to $-36.6 \%$ at the first and second samplings, respectively. The corresponding values for maize were -16.4 to $-36.4 \%$ and -18.9 to -45.9 , respectively. The results obtained were significant, and come along with those reported by Gupt (1993); Marschner (1998) and El-Baalawy (2010).

Application of the organic amendments (compost, biogas manure or humic acid) to the polluted soil treated with heavy metals mixture, generally benefitted the dry matter mass of faba bean and maize plants, at both sampling periods, especially at the lower level $\left(\mathrm{P}_{1}\right)$. Again, at the first growth period, humic acid had a superior influence on the dry matter mass of both plants. However, at the second plant sampling, the action of humic acid was replaced with compost. Increasing the dose of organic amendments gave better curing actions. Similar results were noted by Cynthia et al. (2006); Awad et al. (2010) and Ewais et al. (2011).

\section{Nutrient absorption by faba bean and maize plants}

Data illustrated in Tables ( 7-12 ) showed that, application of the organic sources, each alone to the natural soil at " $\mathrm{P}_{0}$ ", enhanced the plant growth of faba bean and maize, subsequently increased the concentrations and nutrients uptake (nitrogen, phosphorus and potassium), at either growth period for both plants. Remarkable increases in nutrients absorption were observed at the higher level of such organic materials (1.0\%O.C), in comparison with the lower level (0.5 $\%$ O.C) in all experimental treatments. Such increases in nutrients uptake by faba bean and maize plants were certainly accompanied with the corresponding significant augmentation in dry weights of the plants. Humic acid had a superior effect on nutrients uptake, especially at the first plant growth period. Effect of the different types of organic amendments kept the same order noticed for the preceding measures, i.e.: humic acid < biogas manure < compost < control. However, at the second plant sampling, the action of humic acid had moved back to be replaced with compost. Related results were obtained by Ewees and Abd El-Hafeez (2010) and El- Shouny (2011) on wheat plants and Sadek and Sallam (2012) on barely plants.

Egypt. J. Soil Sci. 56, No. 4 (2016) 
جدول 7 
H.M. El-Zemrany et al.

جدول 8

Egypt. J. Soil Sci. 56, No. 4 (2016) 
جدول 9

Egypt. J. Soil Sci. 56, No. 4 (2016) 


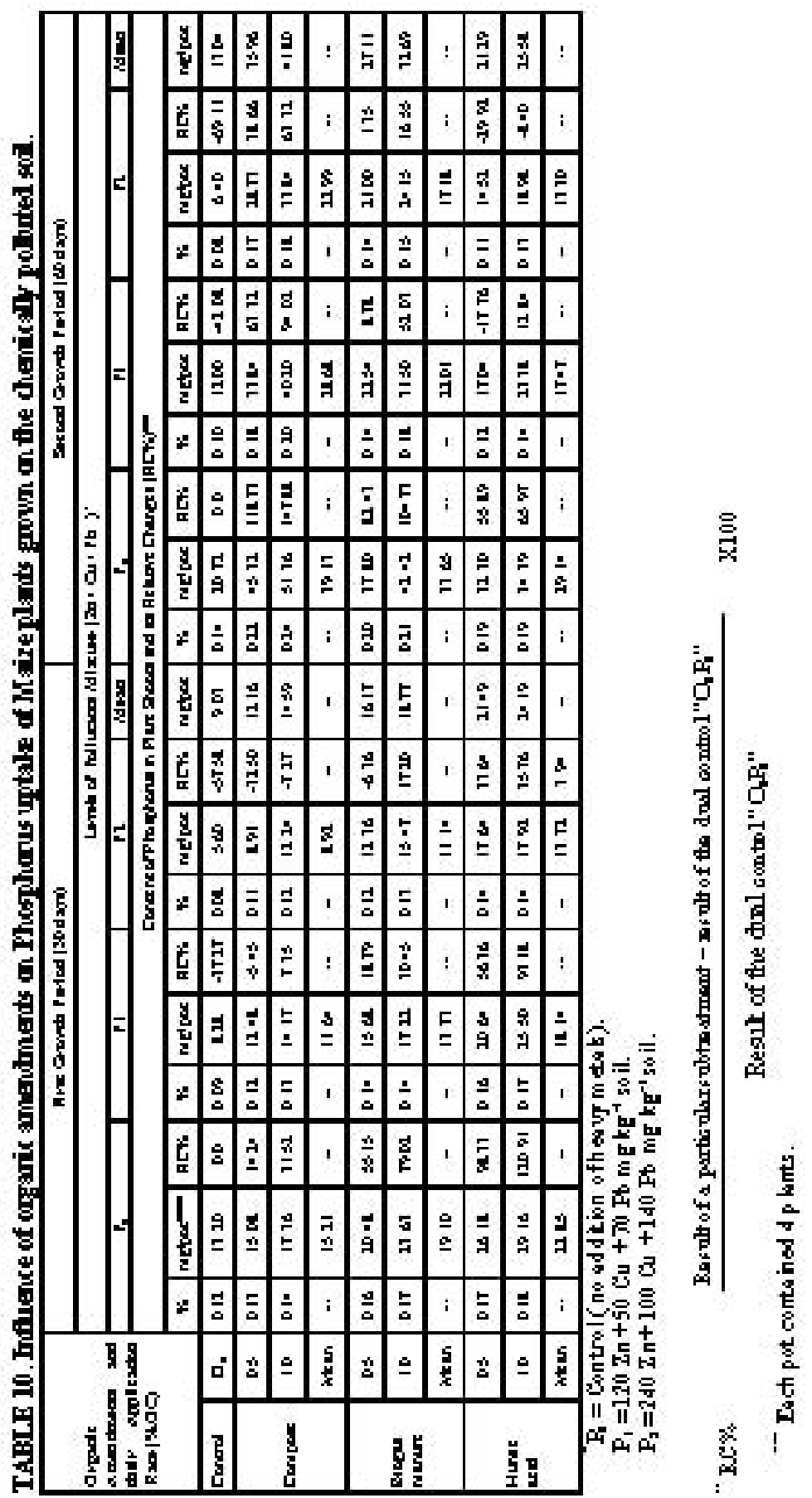

Egypt. J. Soil Sci. 56, No. 4 (2016) 
جدول 11

Egypt. J. Soil Sci. 56, No. 4 (2016) 


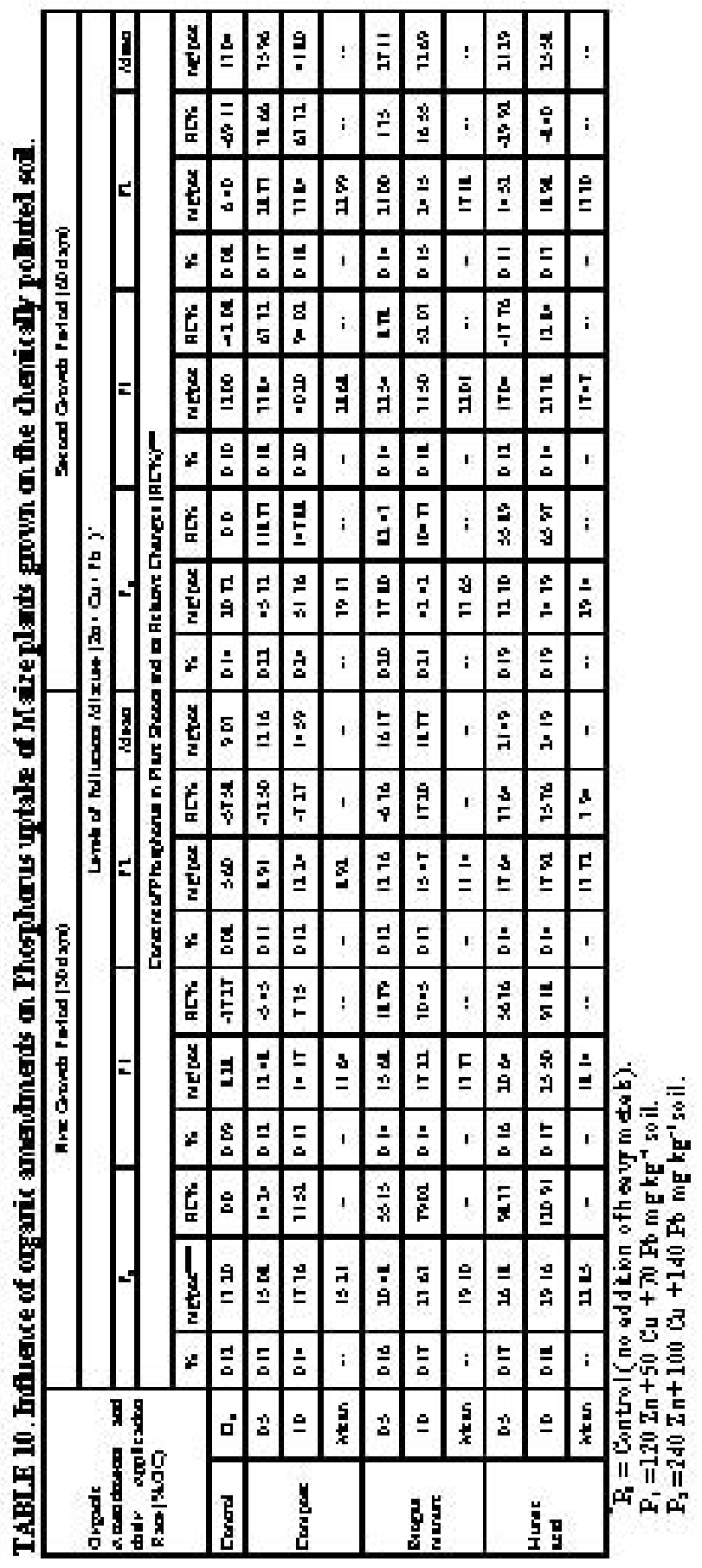


With regard to the effect of heavy metals mixture $(\mathrm{Zn}+\mathrm{Cu}+\mathrm{Pb})$ addition to soil at the two levels $\left(\mathrm{P}_{1} \& \mathrm{P}_{2}\right)$ at $" \mathrm{O}_{0}$ ", on nutrients uptake $(\mathrm{NPK})$, data confirmed the diminution of concentrations and uptake of such nutrients at the first and second growth periods, in a direct relation with the pollutants level (Marschner, 1998; Sheppard, 1998 and Chen et al. 2007).

Concerning the influence of interaction of organic amendments with the heavy metals added, data proved that, the hazardous effect of such pollutants significantly declined in the treated soil, in favour of nutrients absorption by the plants. Order among the organic additives showed consistency with the order of measurements reported at each plant sampling. Similar results were obtained by Awad et al. (2010); Bülent (2012) and Sweed (2013).

An outlook is reviewed herein, for the rates of relative changes "RC\%" of the impact of the applied three organic amendments ( at two rates of each) on absorption of the nutrients "NPK" by faba bean and maize planted in the alluvial clay soil treated with two levels of the assigned heavy metals mixture $\left(\mathrm{P}_{1} \& \mathrm{P}_{2}\right)$. Figures appearing within the parentheses, in the following essence, represent the ranges of $\mathrm{RC}$ values as affected by type and rate of the applied organic amendments (Tables 7 - 12):

\section{Faba Bean Plants:}

1) Nitrogen..

- $1^{\text {st }}$ period: $\mathrm{P}_{0}(0.97$ to $90.91 \%), \mathrm{P}_{1}(-4.26$ to $54.90 \%)$ and $\mathrm{P}_{2}(-20.89$ to $43.86 \%)$

- $2^{\text {nd }}$ period: $\mathrm{P}_{0}(23.25$ to $90.62 \%), \mathrm{P}_{1}(-11.26$ to $62.52 \%)$ and $\mathrm{P}_{2}(-25.93$ to $52.35 \%)$.

2) Phosphorus.

- $1^{\text {st }}$ period: $\mathrm{P}_{0}$ (22.94 to $\left.172.73 \%\right), \mathrm{P}_{1}(.01$ to $98.86 \%)$ and $\mathrm{P}_{2}(-19.48$ to $68.61 \%)$.

- $2^{\text {nd }}$ period: $\mathrm{P}_{0}(47.74$ to $121.25 \%), \mathrm{P}_{1}(-10.10$ to $60.98 \%)$ and $\mathrm{P}_{2}(-31.71$ to $45.59 \%)$

3)Potassium..

- $1^{\text {st }}$ period: $\mathrm{P}_{0}$ (18.33 to $\left.88.52 \%\right), \mathrm{P}_{1}(-5.00$ to $51.80 \%)$ and $\mathrm{P}_{2}(-1545$ to $49.09 \%)$

- $2^{\text {nd }}$ period: $\mathrm{P}_{0}$ (39.84 to $\left.85.85 \%\right), \mathrm{P}_{1}(-4.66$ to $56.22 \%)$ and $\mathrm{P}_{2}(-28.29$ to $45.01 \%)$.

B. Maize Plants:

1)Nitrogen.

- $1^{\text {st }}$ period: $\mathrm{P}_{0}(7.21$ to $87.77 \%), \mathrm{P}_{1}(-11.76$ to $59.09 \%)$ and $\mathrm{P}_{2}(-31.27$ to $35.76 \%)$.

- $2^{\text {nd }}$ period: $\mathrm{P}_{0}(17.42$ to $68.69 \%), \mathrm{P}_{1}(-24.31$ to $50.90 \%)$ and $\mathrm{P}_{2}(-40.54$ to $32.67 \%$ ).

2) Phosphorus.. 
- $1^{\text {st }}$ period: $\mathrm{P}_{0}$ (14.24 to $\left.120.09 \%\right), \mathrm{P}_{1}(-5.46$ to $93.18 \%)$ and $\mathrm{P}_{2}(-32.50$ to $35.76 \%)$.

- $2^{\text {nd }}$ period: $\mathrm{P}_{0}$ (55.89 to $\left.147.88 \%\right), \mathrm{P}_{1}(17.76$ to $94.02 \%)$ and $\mathrm{P}_{2}(-29.92$ to $63.32 \%)$.

3)Potassium

- $1^{\text {st }}$ period: $\mathrm{P}_{0}$ (18.64 to $\left.102.50 \%\right), \mathrm{P}_{1}(-5.45$ to $61.93 \%)$ and $\mathrm{P}_{2}(-35.57$ to $30.91 \%)$.

- $2^{\text {nd }}$ period: $\mathrm{P}_{0}$ (34.21 to $\left.82.65 \%\right), \mathrm{P}_{1}(-7.08$ to $57.25 \%)$ and $\mathrm{P}_{2}(-15.50$ to $33.71 \%)$.

The above mentioned presentation of the results generally verified the higher response of the faba bean plants to the experimental treatments than the maize ones, concerning their effect on NPK contents. Action of the organic additives was entirely beneficial, whenever the extent of this influence relied on type and rate of application, as well as on period of addition, when greater accumulation occurred at the later sampling. Opposite relations occurred between the level of heavy metals mixture and plant age samples in most cases. In absence of pollutants " $\mathrm{P}_{0}$ " and presence of organics, faba bean contents of phosphorus showed the highest accumulation and followed descendingly by nitrogen and potassium. The corresponding values for maize plants exhibited the order: $\mathrm{P}>\mathrm{K}>\mathrm{N}$. Addition of the two levels of heavy metal mixture exerted similar trends to those just reported but at lower values.

The present results confirmed the role of organic materials in controlling the undesirable action of heavy metals pollution in soil, to be positively reflected on plant growth and its traits, e.g. plant height and dry weight depended on the extent of nutrient uptake, and this in turn is directly related with the availability of those nutrients in soil which is affected by many factors. Major among these factors are soil properties, organic matter type and content, and presence of $\mathrm{CaCO}_{3}$ and heavy metals. Heavy metals, besides the detrimental effect of some of them at certain concentrations, they could hinder the availability of nutrients via fixation process. Hence, presence of well decomposed organic materials in soil helps in increasing the availability of plant nutrients by capturing the heavy metals, and thus limiting their unacceptable effect, through chelation process (Marschner, 1998 and Mengel et al., 2001)

The better active response of faba bean than maize to the experimental treatments could be attributed to its nature as a leguminous crop, harbouring the rhizobial bacteria in its roots which provide the growing plants with fixed atmospheric nitrogen and promoting substances, and thus an encouraged growth vigour takes place (Arshad and Frankenberger, 1998 and Dobbelaere et al., 2003). Such criteria made the faba bean plants less susceptible to the heavy metals pollution in soil.

Type of the organic materials applied played an unique role in the extent of controlling the negative effect of the heavy metals added. Despite the favourability of all of them, humic acid excelled biogas manure, whereas Egypt. J. Soil Sci. 56, No. 4 (2016) 
compost was the last, as detected at the first sampling time. Such order came along with the degree of decomposition that indicated by the $\mathrm{C} / \mathrm{N}$ ratio of those materials Table 2 ( $\mathrm{a} \& \mathrm{~b}$ ). The polycarboxylic and phenolic hydroxylic functional groups, being abundant in humic acid (Table $2 \mathrm{~b}$ ), highly contributed to handicapping the mobility of heavy metals in soil medium. Upon advancing the time of plant growth, further microbial decomposition of those organic additives had proceeded. Consequently, structural degradation of humic acid ( having the narrowest $\mathrm{C} / \mathrm{N}$ ratio) had occurred, and on the other side compost (having the widest $\mathrm{C} / \mathrm{N}$ ratio herein), due to its slower release of the active functional groupings of its metabolites, surpassed the others, and to put the humic acid last, whereas biogas manure occupied an intermediate position in both sampling times.

Despite, that the lower level of added heavy metals consisted of the permissible safe limits of each component of the mixture" $\mathrm{P}_{1}$ ", collection of the three elements $(\mathrm{Zn}+\mathrm{Cu}+\mathrm{Pb})$ was somewhat inhibitory. Doubling the elemental concentration in the blend expectedly promoted the harmful impact on the growth of both plants. It is noteworthy that, blending the heavy metals may act together on plant growth either negatively or rarely positively, or each single mineral, in the mixture according to its nature.

Changes detected for the contents of NPK in plant shoot tissues reflected the roles of crop genotype, e.g. the legume faba bean excelled the cereal maize, as well as both differed in their order of superiority among the nutrients themselves. The polyvalent phosphate anions (mostly fixed in soil) came first in both plants as they benefitted from the formation of organo-mineral complexes. However, nitrogen and potassium (usually soluble in soil) exchanged the second and third positions, according to the crop need, whether proteinaceaus as faba bean ( $\mathrm{N}$ - principal) or carbohydrateous as maize (K-principal) (Mengel et al., 2001). Organic amendments represent major sources of nutritional elements, as well as play fundamental roles in physical, chemical and biological properties of soil, in favour of plant growth and crop production. More and above, they considerably bioremediate soil pollution by controlling its undesirable action via chelating the polyvalent heavy metal cations in soil solution and thus decreased their bioavailability, for the benefit of environmental protection and thus provide safety for plants, animals and humans (Chaney, 1994; Ladonin and Margolina, 1997 and Walker et al., 2003).

\section{References}

Abou-El Naga, S.A., El-Shinnawi, M.M. El-Swaaby, M.S. and Salem, M.A. (1999) Chemical pollution of soils, waters and plants at the industrial area of Helwan City in Egypt. Egypt. J. Soil Sci., 39 (3), 263-280.

Adriano, D.C. (2001) Trace Elements in Terrestrial Environments. Biogeochemistry, Bioavailability and Risks of Metals. $2^{\text {nd }}$ ed. Springer-Verlag, New York, USA.

Alloway, B. J. (1995) Heavy Metals in Soils. Blackie Acad. and Profes. $2^{\text {nd }}$ ed. London, U.K.

Egypt. J. Soil Sci. 56, No. 4 (2016) 
Angelova, V., Ivanova, R. Pevicharova, G. and Ivanov, K. (2010) Effect of organic amendments on heavy metals uptake by potato plants. $19^{\text {th }}$ World Congress of Soil Science, Soil Solutions for a Changing World. Brisbane, Australia.

Arshad, M. and W.T. Frankenberger (1998) Plant growth regulating susances in the rhizosphere: microbial production and function. Adv. Agron., 62, 146-161.

Awad, F., Schulz, R. Ruse, R. Breuer, J. and Müller, T. (2010) Sorption of cadmium and copper by organo-clay complexes. Egypt. J. Soil Sci, 50 (1),125-139.

Blaylock, M.J. and Huang, J.W. (2000) Phytoextraction of Metals in: Phytoremediation of Toxic Metals, Rosking and Ensley (Ed.). John Wiley and Sons. New York, USA.

Bülent, T. (2012) The influence of humic acids on the metal bioavailability and phytoextraction efficiency in long-term sludge applied soil. Conference on International Research on Food Security, Natural Resource Management and Rural Development. Gottingen, Germany.

Chaney, R.L. (1994) Soil bioremediation and heavy metal contamination. J. Environ. Quality, 23,1151-1157.

Chen, C.; C.M. Kao; C.F. Chen and C.D. Bong (2007) Distribution and accumulation of heavy metals in the sediments of Kaohsing harbor. Taiwan Chemosphere, 66, $1431-1440$.

Cottenie, A.; M. Verloo.; L. Kiekens.; G. Velghe and R. Camerlyck (1982) Analytical Problems and Methods in Chemical Plant and Soil Analysis. Handbook, Ed. A. Cottenie. Gent, Belgium.

Cynthia, A.C. and N.Y. Raymond (2006) Humic acid preparation, properties and interactions with metals lead and cadmium. Engin. Geology, 85, 26-32.

Dobbelaere, S.; J.Vanderleyden and Y.Okon (2003) Plant growth-promotion of diazotrophs in the rhizosphere. Critical Rev. Plant Sci., 22(2), 107-149.

Eisa, Salwa, A.I.; M.B. Taha and R.N. Habashy (2010) Improving soil productivity for maize yields using some amendments, $\mathrm{Fe}$ and $\mathrm{Zn}$-chelates by different methods of application. Egypt. J. Soil Sci., 50 (1), 1-13.

El-Baalawy, A.M. (2010) Studies on plant nutrition. M.Sc. Thesis, Fac. Agric., Minufiya Univ., Egypt.

El-Shouny, M.M. (2011) Response of wheat plants growing on newly reclaimed sandy soil to bio, organic and mineral fertilizers. Minufiya J. Agric. Res., 36 (2), 457-481.

Ewais, Magda A.; A.A. Mahmoud and M.M. El-Shouny (2011) Comparison between the influence of effective microorganisms (EM) or humic acid (HA) with organic and inorganic fertilizers on wheat plants. Minufiya J. Agric. Res., 36 (3), 795-881.

Ewees, M.S.A. and A.A.A. Abdel Hafeez (2010) Response of maize grain yield to a partial substitution of $\mathrm{N}$ - mineral by applying organic manure, bio-inoculation and Egypt. J. Soil Sci. 56, No. 4 (2016) 
elemental sulphur as an alternative strategy to avoid the possible chemical pollution. Egypt. J. Soil Sci., 50 (1), 141-166.

Gupt, U.C. (1993) Micronutrients content of forages and cereals grown on Prince Edward Island. Canad. J. Soil Sci., 73, 1-7.

Klute, A.(1986) Method of Soil Analysis. Part 2: Physical and Mineralogical Properties. Amer. Soc. Agron. Madison, USA.

Ladonin, D.V. and Margolina, S.E. (1997) Interaction between humic acids and heavy metals. Eurasian Soil Sci., 30, 710-715.

Marschner, H. (1998) Mineral Nutrition of Higher Plants . Acad. Press, Harcount Brace Janovisch Publ. London, UK.

Mengel, K.; H. Kosegarten and T. Appel (2001) Principles of Plant Nutrition. Kluwer Acad. Pub. Dordrecht, The Netherlands.

Page, A.L.; R.H. Miller and D.R. Keeney (1982) Methods of Soil Analysis. Part 2, $2^{\text {nd }}$ ed. Amer. Soc. Agron., Inc. Mad., Wisc., USA.

Papafilippaki, A., D. Gasparatos; C. Haidouti and G. Stavroulakis (2007) Total and available forms of $\mathrm{Cu}, \mathrm{Zn}, \mathrm{Pb}$ and $\mathrm{Cr}$ in agricultural soils: a study from the hydrological basin of keritis, Chania, Greece. Global NEST J., 9 (3), 201-206.

Saad, Shimaa M. (2013) Effect of compost, compost tea and N applied on soil fertility, cucumber growth and resistance of some diseases. M.Sc. Thesis, Fac. Agric., Tanta Univ. Egypt.

Sadek, Jacklin G. and Amany M. Sallam (2012) Effect of grains soaking with micronutrients and foliar nutrition with humic acid on the productivity and quality of barley plant under saline soil conditions. Minufiya J. Agric. Res., 37(4-2), 10491068.

Sheppard, S.C. (1998) Geophagy: Who eats soil and where do possible contaminants go? Environ. Geology, 33, 109-114.

Snedecor, G. W. and N. Cochran (1980) "Statistical Method" $6^{\text {th }}$ ed. The Iowa State Univ. Press. Ames, Iowa, USA.

Stathi, P., Litina, K. Gournis, D. Giannopoulos, T.S. and Deligiannakis, Y. (2007) Physicochemical study of novel organoclays as heavy metal ion adsorbents for environmental remediation. J. Colloid Interface Sci., 316, 298-309.

Sweed, L.M. (2013) Interaction of humic and organic acids with carbonate minerals and calcareous soils. Minufiya J. Agric. Res. 38 (1), 323-324.

Walker, D.J., Clemente, R. Roig, A. and Bernal, M. (2003) The effect of soil amendments on heavy metal bioavailability in two contaminated Mediterranean soils. Environ. Pollution, 22, 303-312.

(Received: $7 / 6 / 2015$

accepted: 12 / 2/ 2017

Egypt. J. Soil Sci. 56, No. 4 (2016) 
H.M. El-Zemrany et al.

\section{مساهمة محسنات عضوية في نمو نباتات الفول البلدي والذرة المزروعة في أراض معرضة للتلوث الكيميائي}

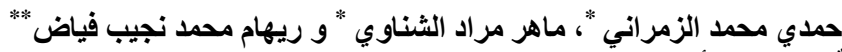

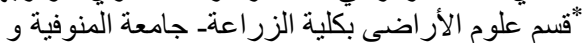

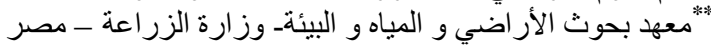

أستخدم كل من حامض الهيوميك و سماد البيوجاز و الكمبوست كمعالج حيوي

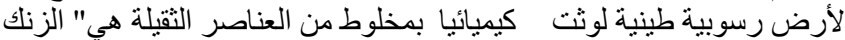

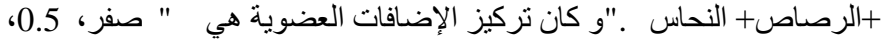

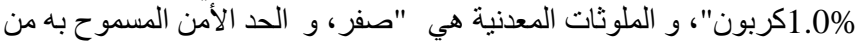

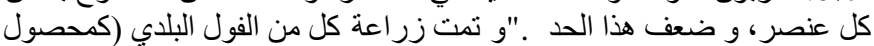

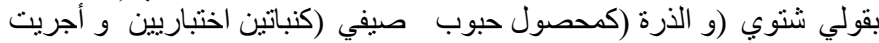

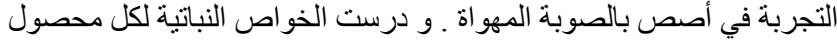
علي فترتي نمو النباتين، و اللتان كانتاللفول " 45 و 90 يوم" و لللذرة" 30 و 60

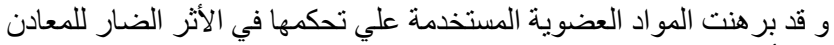

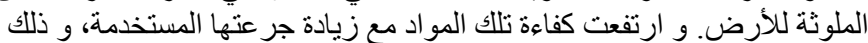

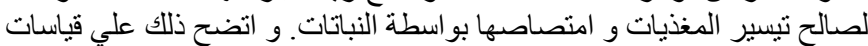

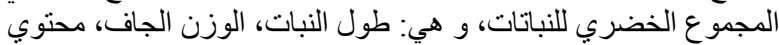

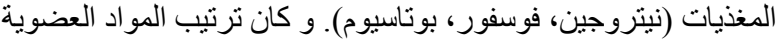

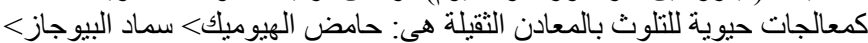

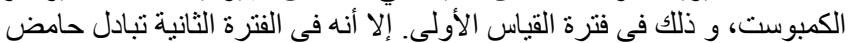

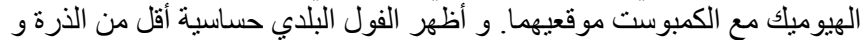
ذللك للتأثير غير المرغوب فيه لتلوث الأرض بالمعادن الثيلية 